\title{
Application of Arbuscular Mycorrhizae and Compost on Growth and Yield of Soybean
}

\author{
St. Subaedah ${ }^{*}$, Andi Ralle ${ }^{2}$ \\ 1,2 Department Agrotechnology Universitas Muslim Indonesia \\ Urip Sumoharjo Road No. 226, Makassar 90231, Indonesia \\ *Corresponding author.E-mail: st.subaedah@umi.ac.id
}

\begin{abstract}
National soybean demand continues to increase in line with the increase in population, while soybean production is still very low. The low production is caused by several factors and one of them is because the development is faced with lands with low soil fertility. Therefore, it is necessary to improve soil fertility, including the use of biological fertilizers such as arbuzcular mycorrhizae along with the provision of compost. This research was conducted with the aim to determine the effect of arbuscular mycorrhizal applications and compost on the growth and production of soybean plants. This research was prepared based on a randomized block design consisting of 5 treatments, namely: control (without mycorrhizal and without compost), mycorrhizal application, mycorrhizal + compost $5 \mathrm{~g} / \mathrm{plant}$, mycorrhizae + compost $10 \mathrm{~g} / \mathrm{plant}$, mycorrhizae + compost $15 \mathrm{~g} / \mathrm{plant}$. After the treatment was repeated three times, so there were 15 experimental units. The results showed that mycorrhizal application accompanied by compost resulted in higher growth and yieldof soybean than without mycorrhizal application and mycorrhizal application without compost.
\end{abstract}

Keywords: Arbuscular mycorrhizae, compost, soybean, growth, yield

\section{INTRODUCTION}

Soybean (Glycine max (L.) Merrill) is one commodity crops are urgently needed in Indonesia, because it can be consumed in a variety of processed food products such as tofu, tempeh, milk, and many other processed products. In addition to soy it also has a relatively high nutrient content, among others, $35 \mathrm{~g}$ protein, $53 \mathrm{~g}$ carbohydrate $18 \mathrm{~g}$ fat and $8 \mathrm{~g}$ of water in $100 \mathrm{~g}$ of food, even for specific high yielding varieties, protein content is 40-43 $\mathrm{g}$ [1].

Efforts to increase the availability of soybeans have become one of the targets of national development in agriculture. This is because the need for soybeans continues to increase in line with the increase in population. In 2018, soybean demand reached 2.5 million tons, while soybean production only reached 82.598 tons [2], so that soybean imports cannot be avoided. Soybean development efforts are faced with low soil fertility due to erosion and land management that does not pay attention to its sustainability aspects [3]. Therefore, efforts are needed to improve land management that can support the sustainability of soybean crop production. One effort that can be done is the use of biological fertilizers, such as arbuscular mycorrhizae. Arbuscular mycorrhiza is a mutually beneficial symbiosis between fungi and plant roots [4].

Arbuscular mycorrhizae infect the root system of the host plant which will intensively produce hyphae interwoven [5], so that mycorrhizal plants will be able to increase nutrient and water absorption capacity [6], and increase plant resistance to soil salinity stress [7].

The effectiveness of mycorrhizae in increasing nutrient availability to improve plant growth depends on the type of mycorrhizae itself, the type of host plant, and also very much depends on soil types, especially soil $\mathrm{pH}$ and fertility levels and their interactions [8]. Furthermore, [9] suggests that the activity of microorganisms in the soil is influenced, among others, by the level of organic matter in the soil, because organic matter is used by microorganisms as their energy source. To increase the level of soil organic matter can be reached by using organic fertilizers, such as compost. Based on this description, a research was conducted on the effect of mycorrhizal and compost applications on the growth and yield of soybean plants. 


\section{RESEARCH OF METHODS}

This research was conducted in an experimental form at the Green House of the Faculty of Agriculture and Soil Laboratory of the Universitas Muslim Indonesia, Makassar, South Sulawesi, Indonesia. This research took place from April to August 2020.

The tools used in this study were polybags, shovels, analytical scales, hand sprayer, plant labels, oven, sieve, bucket, tape measure, camera and writing instruments. While the materials used in this study were soil, sand, compost, soybean seeds, mycorrhizal, distilled water and alcohol.

This research was prepared based on a randomized block design (RBD) which consisted of 5 treatments, namely:

M0: Control (without mycorrhizal and without compost) M1: Mycorrhiza

M2: Mycorrhizae + compost $5 \mathrm{~g} /$ plant

M3: Mycorrhizae + compost $10 \mathrm{~g} /$ plant

M4: Mycorrhizae + compost $15 \mathrm{~g} /$ plant

Each treatment was repeated three times in order to obtain 15 experimental units.

\subsection{Trial Implementation}

This research was conducted in several stages, namely the preparation of planting media, planting and mycorrhizal inoculation, maintenance and observation. Each stage will be described as follows:

\subsubsection{Preparation of Planting Media}

The planting medium used was soil and sand with a ratio of 2: $1(\mathrm{v} / \mathrm{v})$. The media is then weighed as much as $8 \mathrm{~kg} /$ polybag, before being put into a poly bag, for treatment of M2, M3 and M4 the planting media is mixed with compost according to the specified treatment dose. After all the planting media has been put in a poly bag, it is then arranged according to the predetermined research plan.

\subsubsection{Seed Planting and Mycorrhizal Inoculation}

Soybean seeds are planted in the planting medium that has been provided. One polybag is planted with 3 soybean seeds, with the aim of anticipating that if one seed dies, there are still two living seeds. Furthermore, when the plants were two weeks old, $10 \mathrm{~g} /$ plant of mycorrhizae were administered.

\subsubsection{Maintenance}

The maintenance stage is carried out for approximately 3 months. Soybean plants are placed in a place that gets enough sunlight. Watering is carried out according to soil moisture conditions. NPK fertilization with a low dose of $150 \mathrm{~kg} / \mathrm{ha}$.
The variables observed in this study were: plant height, number of leaves, number of branches, number of pods per plant, weight of pods per plant and weight of seeds per plant.

Data from observations in the field were analyzed using the randomized block design method and then if the treatment had a significant effect, then it was followed by the LSD test at the level $\alpha 0.05$

\section{RESULTS AND DISCUSSION}

\subsection{Results}

\subsubsection{Plant height}

The observation result of soybean plant height at 8 weeks after planting (WAP) showed that the application of mycorrhiza and compost did not significantly affect plant height. The average height of soybean plants at the age of 8 MST which is presented in Figure 1 shows that the treatment of mycorrhizal applications (M1) without compost tends to obtain higher soybean plants, namely $42.00 \mathrm{~cm}$ compared to other treatments.

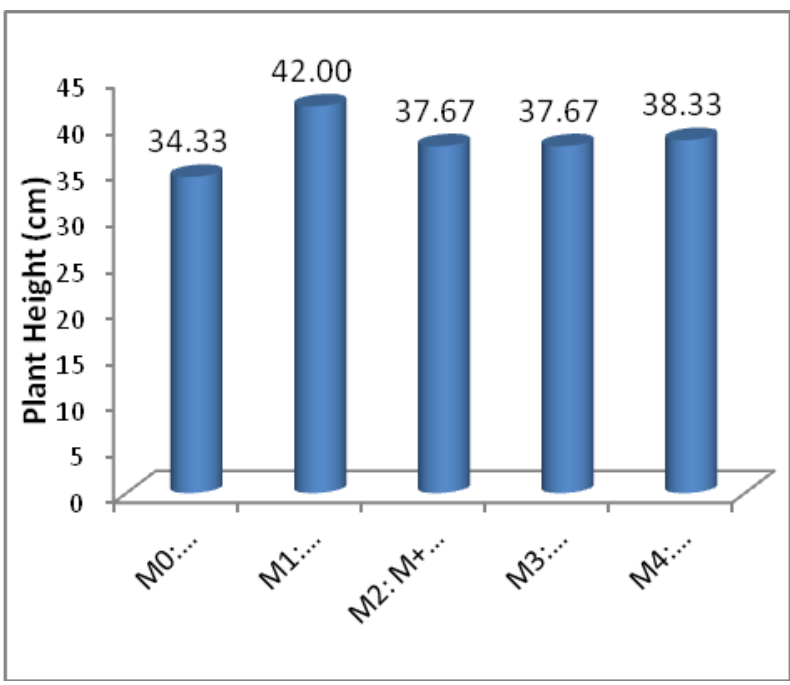

Figure 1. Effect of Arbuscular Mycorrhizae and Compost Application on Soybean Plant Height at Age 8 WAP

\subsubsection{Number of Leaves}

Mycorrhizal and compost applications showed a significant effect on the number of soybean leaves at the age of 8 WAP. The results of the LSD further test in Table 1 show that the application of mycorrhizae with the addition of $5 \mathrm{~g}$ of compost (M2) obtained a higher number of leaves, namely 28.67 strands and significantly different from other treatments (M0, M3 and M4) but not different from the treatment of mycorrhizal applications without compost (M1). 
Table 1. The Effect of Mycorrhizal and Compost Applications on the Number of Soybean Plant Leaves at 8 WAP

\begin{tabular}{lcc}
\hline \multicolumn{1}{c}{ Treatment } & $\begin{array}{c}\text { Number of } \\
\text { Leaves }\end{array}$ & $\begin{array}{c}\text { LSD } \\
\alpha 0.05\end{array}$ \\
\hline M0: Control & $13.33 \mathrm{~b}$ & 8.52 \\
M1: Mycorrhizae & $21.00 \mathrm{ab}$ & \\
M2: $\mathrm{M}+5 \mathrm{~g} \mathrm{C}$ & $28.67 \mathrm{a}$ & \\
M3: $\mathrm{M}+10 \mathrm{~g} \mathrm{C}$ & $20.00 \mathrm{~b}$ & \\
M4: $\mathrm{M}+15 \mathrm{~g} \mathrm{C}$ & $16.00 \mathrm{~b}$ & \\
\hline
\end{tabular}

Note: The values followed by the same letters are not significantly on the LSD level of $\alpha 0.05$

\subsubsection{Number of Branches}

The results of data analysis on the number of branches showed that the application of mycorrhizal and compost did not significantly affect the number of soybean branches. However, the results of the average value of the number of branches presented in Figure 2 indicate that the treatment of mycorrhizal administration with the addition of $5 \mathrm{~g}$ of compost (M2) tended to obtain more branches, namely 11 branches compared to other treatments.

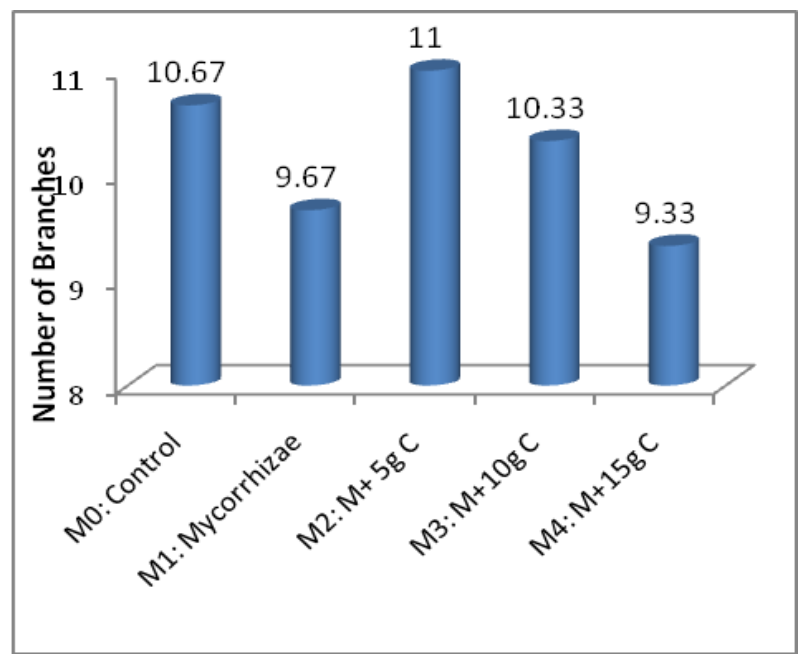

Figure 2. Effect of Mycorrhizal and Compost Applications on the Number of Branches

\subsubsection{Number of Pods}

Observation of the number of pods showed that the application of mycorrhizal and compost significantly affected the number of soybean pods produced. The average number of soybean pods per plant is presented in Table 2 shows that the highest number of pods was obtained in the mycorrhizal application treatment with the addition of $10 \mathrm{~g}$ (M3) compost, namely 57.67 pods followed by mycorrhizal application treatment with the addition of $5 \mathrm{~g}$ of compost (M2). and significantly different from the number of soybean pods produced in the control treatment, namely without mycorrhizal and without compost (M0) but not significantly different from other treatments (M1, M3 and M4).

Table 2. Average Number of Soybean Pods with Mycorrhizal and Compost Applications

\begin{tabular}{lcc}
\hline \multicolumn{1}{c}{ Treatment } & $\begin{array}{c}\text { Number of } \\
\text { Soybean Pods }\end{array}$ & $\begin{array}{c}\text { LSD } \\
\alpha 0.05\end{array}$ \\
\hline M0: Control & $36.67 \mathrm{~b}$ & 12.04 \\
M1: Mycorrhizae & $46.00 \mathrm{ab}$ & \\
M2: M+ 5g C & $57.00 \mathrm{a}$ & \\
M3: M+10g C & $57.67 \mathrm{a}$ & \\
M4: M+15g C & $51.67 \mathrm{a}$ & \\
\hline
\end{tabular}

Note: The values followed by the same letters are not significantly on the LSD level of $\alpha 0.05$

\subsubsection{Pod Weight}

The results of data analysis on soybean pod weight per plant showed that the application of mycorrhizal and compost had a significant effect. In Table 3 , the average weight of soybean pods per plant is presented and shows that the application of mycorrhizal treatment and the addition of $5 \mathrm{~g}$ of compost per plant (M2) obtained the heaviest weight of soybean pods per plant, namely $52.28 \mathrm{~g}$ and significantly different from other treatments (M0, M1 and M4) but not significantly different from the application of mycorrhizal treatment and the addition of $10 \mathrm{~g}$ of compost (M3).

Table 3. Average pod weight per plant (g) with mycorrhizal and compost application

\begin{tabular}{lcc}
\multicolumn{1}{c}{ Treatment } & $\begin{array}{c}\text { Pod Weight } \\
(\mathrm{g})\end{array}$ & $\begin{array}{c}\text { LSD } \\
\alpha 0.05\end{array}$ \\
\hline M0: Control & 19.89 & 13,85 \\
M1: Mycorrhizae & 31.99 & \\
M2: M+ 5g C & 52.28 & \\
M3: M+10g C & 43.22 & \\
M4: M+15g C & 34.20 & \\
\hline
\end{tabular}

Note: The values followed by the same letters are not significantly on the LSD level of $\alpha 0.05$

\subsubsection{Seed Weight Per Plant}

The results of observations on the weight of soybean seeds per plant showed that the application of mycorrhizae and compost had a significant effect. The results of the LSD follow-up test in Table 4 show that the heaviest weight of soybean seeds per plant was obtained in the application of mycorrhizal application of $5 \mathrm{~g}$ of compost per plant (M2), which was $28.04 \mathrm{~g}$ and was significantly different from the control treatment 
(without mycorrhizal and without compost) and also significantly different from the application of mycorrhizal treatment without compost (M1).

Table 4. Average weight of soybean seeds (g) per plant using mycorrhizal and compost applications

\begin{tabular}{lcc}
\hline \multicolumn{1}{c}{ Treatment } & $\begin{array}{c}\text { Seed Weight } \\
(\mathrm{g})\end{array}$ & $\begin{array}{c}\text { LSD } \\
\alpha 0,05\end{array}$ \\
\hline M0: Control & $13.35 \mathrm{c}$ & 9.19 \\
M1: Mycorrhizae & $19.23 \mathrm{bc}$ & \\
M2: M+ 5g C & $28.04 \mathrm{a}$ & \\
M3: M+10g C & $23.04 \mathrm{ab}$ & \\
M4: M+15g C & $23.63 \mathrm{ab}$ & \\
\hline
\end{tabular}

Note: The values followed by the same letters are not significantly on the LSD level of $\alpha 0.05$

\subsection{Discussion}

The results of the data analysis showed that the application of mycorrhizae and compost had a significant effect on the growth and production of soybean as indicated by the parameters of the number of leaves, number of branches, pod weight and seed weight per plant. The results of this study are in line with the findings of [10], who found that soybeans given mycorrhizal treatment affected growth, yield components and soybean yield. Likewise, the results of [11] study found that the application of mycorrhizae resulted in better soybean plant growth.

The good effect of mycorrhizal applications on the growth and production of soybean plants is due to the potential for mycorrhizae to infect the root system of the host plant and will produce hyphae intensively so that mycorrhizal plants will be able to increase their capacity to absorb nutrients and water [5]. The results of research by [12] showed that arbuscular mycorrhizae can increase apple plant growth and increase the resistance of apple plants to disease. Likewise, research conducted by [13] which reported that the application of mycorrhizae to gandung plants increased production by up to $40 \%$. The good effect of mycorrhizae on increasing plant production was also reported by [14] that mycorrhizal applications in soybean plants increased soybean production and also from this study it was found that mycorrhizal applications increased the availability of phosphorus by $34 \%$ compared to without mycorrhizal applications (without mycorrhizal applications. availability of $4.03 \mathrm{ppm}$ of phosphorus, and increased to $5.41 \mathrm{ppm}$ with mycorrhizal applications. Increased availability of phosphorus is very significant for plant growth, because Phosphorus is one of the important macro nutrients in plant growth and development; it functions as a constituent of metabolites in complex compounds, as an activator, cofactor or fiber enzyme unifier and plays a role in physiological processes and is also a structural component. Of a number of important compounds, the energy transfer molecules ADP and ATP [15].
The results of this study also showed that mycorrhizal application treatment accompanied by the application of compost as much as $5 \mathrm{~g}$ per plant showed a higher production as indicated by the pod weight per plant and seed weight per plant compared to without compost and compost application with a higher dose. This is due to the mycorrhizal effectiveness, among others, influenced by soil fertility, particularly soil $\mathrm{P}$ content. The application of compost can increase the soil organic matter content which in turn will increase the movement and availability of $\mathrm{P}$ nutrients in the soil, so that with more compost doses it allows the availability of more $\mathrm{P}$ nutrients and results in decreased effectiveness of mycorrhizae. This is consistent with the findings of [16] who stated that mycorrhizal associations tend to decrease when the $\mathrm{P}$ concentration in plants increases. Higher $P$ availability can reduce spore production [17] and limits the role of mycorrhizae in improving plant growth [18]. Therefore, increasing the $\mathrm{P}$ status of the roots would reduce hyphae branching and mycorrhizal associations.

\section{CONCLUSION}

The application of mycorrhizae accompanied by $5 \mathrm{~g}$ of compost per plant obtained the highest number of leaves and pods, as well as the heaviest pod weight and seed weight.

\section{ACKNOWLEDGMENTS}

Thanks to the Ministry of Research and Technology and Higher Education (RISTEK-DIKTI) of the Republic of Indonesia for providing financial assistance, and Universitas Muslim Indonesia so that this research can be carried out.

\section{REFERENCES}

[1] Suprapto, Bertanam Kedelai, Penebar Swadaya. Jakarta, 2001.

[2] CBS, Indonesian Statistics, 2019. http://www.bps.go.id

[3] St. Subaedah, Agroteknologi Lahan Kering. Nas Media Pustaka, Makassar, 2018.

[4] S. E. Smith, F. A. Smith. Fresh perspectives on the roles of arbuscular mycorrhizal fungi in plant nutrition and growth. Mycologia, vol. 104, no. 1, 2012, pp. 1-13. DOI: 10.3852/11-229

[5] H. Talanca, Status cendawan Mikoriza VesicularArbuskular (MVA) pada tanaman, In Prosiding Pekan Serelia Nasional, 2010, pp. 353-357.

[6] T. Buechel and E. Bloodnick, Mycorrhizae: descriptionof types, benefits and uses, Plant Healt. 2016. 
[7] D. R. R. Damaiyanti, N. Aini, and R. Soelistyono, Effects ofarbuscular mycorrhiza inoculation on growth and yield oftomato (Lycopersicum esculentum Mill) under salinity stress, J. Of Degraded and Mining Lands Management, vol. 3, no.1, 2015, pp. 447-452.

[8] M. C. Brundrett, N. Ashwath, and D.A. Jasper, Mycorrhizas in the Kakadu region oftropical Australia. I. Propagules of mycorrhizal fungi and soil properties in naturalhabitats, Plant and Soil 184, 1996, pp. 159-171.

[9] R. Sutanto, Pertanian Organik, Yogyakarta: Kanisius, 2005.

[10] W. Haryoko dan Y. M. Zen, Pengaruh Flavonoid dan Cendawan Mikoriza Arbuskula Terhadap Pertumbuhan dan Hasil Kedelai Pada Ultisol, J. Stigma, 4, 2003, pp. 352-356.

[11] T. Turmuktini, Interaksi antara dosis fungi mikoriza arbuskula terhadap pertumbuhan, kuantitas dan kualitas tiga kultivar kedelai, Jurnal Hayati, 3, 2009, pp. 79-83.

[12] D. Berdeni, T. E. A. Cotton, T. J. Daniell, M. I. Bidartondo, D. D. Cameron, and K. L. Evans, The Effects of Arbuscular Mycorrhizal Fungal Colonisation on Nutrient Status, Growth, Productivity, and Canker Resistance of Apple (Malus pumila), Frontiers in Mycrobiology, 9, 2018. DOI:10.3389/fmicb.2018.01461
[13] X. C. Cui, J. L. Hu, X. G. Lin, F. Y. Wang, R. R. Chen, J. H. Wang, and J. G. Zhu, Arbuscular Mycorrhizal Fungi Alleviate Ozone Stress on Nitrogen Nutrition of Field Wheat, J. Agr. Sci. Tech. 15, 2013, pp.1043-1052.

[14] St. Subaedah, S. S. Netty, and A. Ralle, Growth and Yield of Two Soybean Varieties by Phosphate Fertilization and Arbuscular Mycorrhizal Application, J. Biological of Sciences, vol. 20, no.4, 2020, pp. 147-152. DOI: 10.3923/jbs.2020.147.152

[15] F. P. Gardner, R. B. Pearce, and R. L. Mitchell, Physiology of Crop Plant, Iowa State University Press, Ames. Iowa, 1995

[16] C. Grant, S. Bittman, M. Montreal, C. Plenchette, and C. Morel, Soil and fertilizer phosphorus: Effects on plant $\mathrm{P}$ supply and mycorrhizal development, Can. J. Plant Sci. 85, 2005, pp. 3-14

[17] J. C. C. de Miranda and P. J. Harris, Effects of soilphosphorus on spore germination and hyphal growth of arbuscularmycorrhizal fungi, New Phytol. 128, 1994, pp. 103-108

[18] T.M. Bowles, L.E. Jackson, and T.R. Cavagnaro. Mycorrhizal fungi enhance plant nutrient acquisition and modulate nitrogen loss with variable water regimes, Glob. Change Biol, vol. 24, 2017, pp. 171-182. DOI: 10.1111/gcb.13884 